\title{
Нейрометаболічна стратегія фармакотерапії афективних розладів: кому, коли і навіщо?
}

\author{
С.Г. Бурчинський \\ Державна установа «Інститут геронтології імені Д.Ф. Чеботарьова НАМН України», Київ, Україна
}

Анотація. Однією з найважливіших із клінічної точки зору проблем, пов'язаних із діагностикою та лікуванням депресії, особливо в загальномедичній та неврологічній практиці, $\epsilon$ значне почастішання випадків афективних розладів, які отримали назву дистимії, тобто станів психоемоційної сфери, що характеризуються нестійкістю настрою чи переважанням зниженого психоемоційного фону, відчуттям пригніченості, байдужості, яке, однак, не $\epsilon$ стабільним і періодично змінюється нормальним сприйняттям себе і оточення. Такі стани, не будучи депресією у суворо нозологічному сенсі цього терміна, можуть передувати розвитку депресивного розладу, а можуть характеризуватися стабільністю протягом досить тривалого часу. При дистимії призначення «класичних» антидепресантів далеко не завжди $є$ показаним. У цій ситуації більш корисними можуть бути так звані тимостабілізатори, або коректори настрою, лікарські засоби з м'яким комплексним механізмом дії на психоемоційну сферу, які підвищують настрій і життєвий тонус без вираженого впливу на психопатологічну симптоматику. Одним із таких засобів, який принципово відрізняється від конвенційних антидепресантів і характеризує іншу стратегію впливу - нейрометаболічну, $є$ інноваційний вітчизняний комплекс Депріліум ${ }^{\oplus}$, до складу якого входять S-аденозил-L-метіонін, L-метилфолат і метилкобаламін.

Ключові слова: афективні розлади, депресія, депресивні розлади, дистимія, антидепресанти, тимостабілізатори, Депріліум ${ }^{\circledast}$ S-аденозил-L-метіонін, L-метилфолат, метилкобаламін.

Останніми роками проблема депресій стала однією з найактуальніших не лише у психіатричній практиці, але й у глобальному медичному масштабі. За даними Всесвітньої організації охорони здоров'я (що не враховують значної кількості недіагностованих, маскованих, соматоформних та інших варіантів), депресивні розлади різної природи діагностують у $>4 \%$ населення Землі (а в похилому і старечому віці - у 13-18\%), при цьому тільки за період 2005-2015 рр. кількість діагностованих випадків депресії збільшилася майже на 20\% [1, 2].

Найважливішою відмінною рисою депресивних станів на сучасному етапі $\epsilon$ їх вихід за межі психіатричної патології, неухильне підвищення питомої ваги невротичних і соматогенних форм порівняно із класичною ендогенною депресією (моно- і біполярними розладами) [3]. Так, на сьогодні частка непсихотичних форм у загальній структурі депресивної патології перевищує $60 \%$ [2]. Саме цим зумовлений той факт, що в останні роки все більша кількість таких хворих звертаються не до психіатра, а до лікаря первинної ланки - сімейного лікаря, або у разі соматогенної депресії - до лікарів інших спеціальностей (кардіолога, невролога, гастроентеролога тощо), а часто взагалі уникають контактів з офіційною медициною, не вважаючи себе хворими або вважаючи за краще лікуватися самостійно за допомогою нетрадиційних методів.

Результатами цього $\epsilon$ дві принципові обставини: 1) зростання кількості хронічних рецидивуючих форм із затяжними епізодами загострень, підвищення частоти суїцидів; 2) необхідність для лікарів усіх спеціальностей вміння розпізнавати депресивну природу захворювання на тлі численних скарг невротичного, кардіологічного та іншого характеру і вміння орієнтуватися в сучасних стратегіях фармакотерапії цієї патології.

Крім того, однією $з$ найважливіших із клінічної точки зору проблем, пов'язаних із діагностикою та лікуванням депресії, особливо в загальномедичній та неврологічній практиці, $\epsilon$ значне почастішання випадків афективних розладів, які отримали назву дистимії, тобто станів психоемоційної сфери, що характеризуються нестійкістю настрою чи переважанням зниженого психоемоційного фону, відчуттям пригніченості, байдужості, яке, однак, не $\epsilon$ стабільним і періодично змінюється нормальним сприйняттям себе і оточення. Такі стани, не будучи депресією у суворо нозологічному сенсі цього терміна, можуть передувати розвитку депресивного розладу, а можуть характеризуватися стабільністю протягом досить тривалого часу. Зокрема дистимії $\epsilon$ досить типовою ознакою передменструального дисфоричного розладу, клімактеричного синдрому, станів хронічного стресу («синдром менеджера»), нейроциркуляторної дистонії, різних форм психосоматичної патології тощо.

При дистимії призначення «класичних» антидепресантів далеко не завжди $\epsilon$ показаним. У цій ситуації більш корисними можуть бути так звані тимостабілізатори, або коректори настрою, - лікарські засоби з м'яким комплексним механізмом дії на психоемоційну сферу, які підвищують настрій і життєвий тонус без вираженого впливу на психопатологічну симптоматику.

Успішність терапії у пацієнтів із депресивними розладами у загальномедичній практиці у результаті визначається такими обставинами:

- правильний діагноз;

- ранній початок терапії;

- вибір адекватного антидепресанта/тимостабілізатора.

Сьогодні препарати антидепресантів широко представлені на світовому фармацевтичному ринку, зокрема в Україні, однак при цьому відзначається досить високий ступінь незадоволеності результатами фармакотерапії у разі депресій - як серед клініцистів, так і серед пацієнтів [4], пов'язаний з наявністю:

- досить великої (до 30\%) популяції пацієнтів, резистентних до терапії відомими препаратами антидепресантів;

- суттєвої затримки (2-4 тиж) у часі розвитку клінічних ефектів цих препаратів;

- значних із клінічної точки зору побічних ефектів практично в усіх засобів цієї групи $[5,6]$.

До основних груп застосовуваних сьогодні препаратів антидепресантів можна віднести трициклічні антидепресанти (ТЦА) і селективні інгібітори зворотного захоплення серотоніну (CI33C). ТЦА - класичні антидепресанти із багаторічним досвідом застосування в усьому світі. Маючи виражену антидепресивну активність, ТЦА поклали початок створенню препаратів спрямованої дії на катехоламін- і серотонінергічні нейромедіаторні системи і відкрили нову еру в лікуванні пацієнтів із депресивними станами. Водночас їх застосування досить часто супроводжується численними серйозними побічними ефектами, зокрема небезпечними для життя (антихолінергічні ефекти - затримка сечі, порушення акомодації, психічні розлади; серцево-судинні ортостатична гіпотензія, порушення міокардіальної провідності та серцевого ритму тощо). Усе вищезазначене, а також наявність численних, часто небезпечних міжлікарських взаємодій з іншими препаратами, призвело до значного скорочення застосування цих засобів і внаслідок цього - до зменшення їх обсягів на фармацевтичному ринку. 
CI33С на сьогодні - найбільш популярна і численна за номенклатурою група антидепресантів. Висока вибірковість дії, відносно незначна кількість побічних реакцій, виражена ефективність сприяли підвищенню частоти їх застосування за останні десятиліття при різних клінічних формах депресивних станів. Однак і ці препарати у певної кількості резистентних до них пацієнтів можуть виявитися неефективними. Необхідність титрування дози при їх застосуванні ускладнює широке впровадження препаратів CI33С у загальномедичну практику. Крім того, Сl33С не позбавлені ряду небажаних реакцій при застосуванні, зокрема досить часто відзначають нудоту (21-26\%) і порушення сну (13-16\%), а також більш рідкісне, але серйозне ускладнення - сексуальну дисфункцію (1-3\%) [7]. Нарешті, і СІ33С, і тим більше - ТЦА, не $\epsilon$ препаратами вибору для корекції дистимічних розладів, коли кориснішими можуть бути так звані тимостабілізатори, або коректори настрою, - лікарські засоби з м'яким комплексним механізмом дії на психоемоційну сферу, які підвищують настрій і життєвий тонус без вираженого впливу на психопатологічну симптоматику.

3 огляду на вищезазначене цілком виправданим $\epsilon$ інтерес фармакологів і клініцистів до пошуку та впровадження у практику нових альтернативних препаратів, які не поступаються за ефективністю зазначеним групам лікарських засобів, але перевершують їх за критерієм безпеки і в ряді випадків - за широтою терапевтичного застосування, при цьому здатних також виконувати роль тимостабілізатора. Особлива необхідність у цих препаратах $\epsilon$ насамперед при психоемоційних розладах у рамках психосоматичної патології, при нейроциркуляторній дистонії, соматоформних больових розладах, стресозалежних патологічних станах («синдром менеджера») тощо, тобто в ситуаціях повсякденної практики сімейного лікаря, невролога тощо.

Одним із таких засобів, який принципово відрізняється від конвенційних антидепресантів і характеризує іншу стратегію впливу - нейрометаболічну, $\epsilon$ інноваційний вітчизняний комплекс Депріліум ${ }^{\oplus}$, до складу якого входять:

- S-аденозил-L-метіонін - 200 мг;

- L-метилфолат - 0,4 мг (що еквівалентно 0,4 мг фолієвої кислоти;

- вітамін $\mathrm{B}_{12}$ (у формі метилкобаламіну) - 0,25 мг.

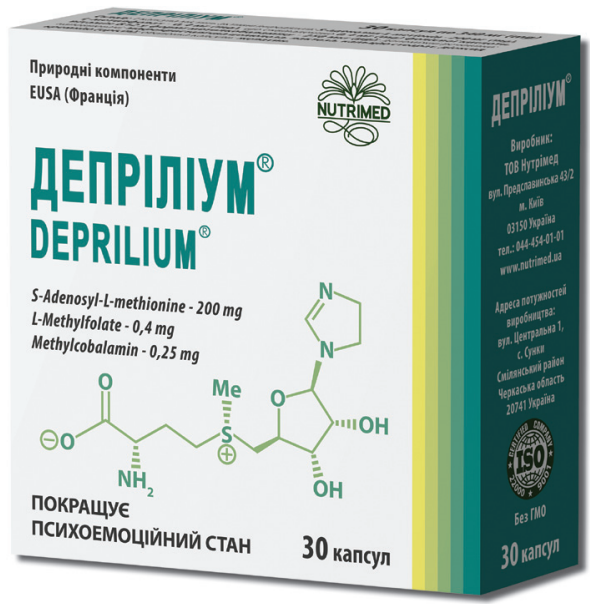

Чим же зумовлений вибір зазначених компонентів при лікуванні афективних розладів і які можливості й переваги цієї комбінації?

S-aденозил-L-метіонін (SAM) - природна сполука в організмі людини, донатор активних метильних груп, що беруть участь у багатьох фізіологічних реакціях і, перш за все - в головному мозку $[8,9]$. Екзогенно введений SAM легко проникає через гематоенцефалічний бар'єр і відіграє важливу роль у біосинтезі гормонів, нейромедіаторів, нуклеїнових кислот, фосфоліпідів тощо. Щодо впливу на патогенез депресивних розладів особливий інтерес становить активація під його дією шляхів біосинтезу норадреналіну, дофаміну і серотоніну — трьох основних біогенних амінів, зниження концентрації яких у центральній нервовій системі (ЦНС) розглядають як основний механізм розвитку депресії $[8,10]$. Показано стимулювальний вплив SAM на ключові ланки біосинтезу біогенних амінів, зокрема на активацію ферментного кофактора тетрагідробіоптерину $\left(\mathrm{BH}_{4}\right)$, а також на ослаблення активності ферментів їх катаболізму і процесів зворотного захоплення у синаптичній щілині, та, крім того, підвищення спорідненості цих амінів до специфічних рецепторних структур [11]. Таким чином, SAM можна розглядати не лише як безпосередній активатор синтезу біогенних амінів, але і як модулятор практично всіх процесів фізіологічного ланцюга: біосинтез - вивільнення - зворотне захоплення - рецепторне зв'язування норадреналіну, дофаміну і серотоніну, а також як фактор, що відіграє роль у корекції важливої ланки патогенезу депресії - структурно-функціональної характеристики нейрональних мембран (активація біосинтезу фосфоліпідів і захист від шкідливої дії вільнорадикального окиснення). У пацієнтів із депресивними розладами відзначають зниження концентрації SAM у спинномозковій рідині, а підвищення його концентрації у плазмі крові тісно корелює з ослабленням депресивної симптоматики [12].

Сьогодні у світі SAM розглядають як один з найбільш широко застосовуваних і перспективних природних антидепресантів [8, $13,14]$. Його використання має солідну доказову базу, засновану на результатах рандомізованих подвійних сліпих плацебоконтрольованих досліджень. SАM продемонстрував достовірно вищу тимоаналептичну активність порівняно із плацебо, зіставну за вираженістю з препаратами ТЦА при депресії легкої та середньої тяжкості [15]. При цьому параметри Шкали Гамільтона для оцінки депресії (Hamilton Depression Rating Scale - HAMD) поліпшувалися на 5-6 пунктів після застосування SAM в режимі монотерапії у дозі 200-800 мг/добу при парентеральному і 400-1200 мг/добу - при пероральному застосуванні $[8,16]$. Найважливіша перевага SAM у цих дослідженнях - виявлення максимально ранньої відповіді на терапію (протягом 1-го на початку 2-го тижня лікування), що істотно перевищує швидкість відповіді на препарати ТЦА або СІ33С [13].

У цьому відношенні особливий інтерес становить можливість застосування SAM як іншої стратегії лікування - аугментації, тобто посилення клінічного ефекту у пацієнтів-нонреспондерів або у разі недостатньої ефективності застосування найпопулярніших сьогодні антидепресантів - $\mathrm{Cl} 33 \mathrm{C}$ і селективних інгібіторів зворотного захоплення серотоніну і норадреналіну $(\mathrm{Cl} 33 \mathrm{CH})$. Проведені масштабні клінічні випробування щодо включення SAM як інструменту аугментації у пацієнтів із недостатньою відповіддю на есциталопрам або венлафаксин продемонстрували приблизно дворазове збільшення кількості пацієнтів-респондерів, а також більш виражений антидепресивний ефект у пацієнтів, які отримували SAM, порівняно $з$ контрольною групою, в якій застосовували лише монотерапію антидепресантом $[10,17]$. Ефекти SAM порівняно з есциталопрамом більш виражені саме на ранніх стадіях терапії (перші 2-6 тиж), але нівелювалися з продовженням лікування (на 8-12-му тижні), що підтверджує характеристику швидкості дії як найважливішу складову клінічного ефекту SAM [18]. 3 огляду на вищезазначену частоту фармакорезистентності до антидепресантів розглянута дія SAM може зробити істотний внесок в удосконалення стратегії аугментації. Крім того, застосування SAM у ад'ювантній терапії при депресії дозволяє мінімізувати ефективну дозу СІ33С або $\mathrm{Cl} 33 \mathrm{CH}$ і завдяки цьому знизити ризик розвитку побічних ефектів цих засобів, особливо при їх поганій переносимості в умовах тривалого курсового застосування. У результаті застосування SAM у рамках стратегії аугментації не лише підвищує ефективність конвенційних антидепресантів, але й сприяє зниженню ризиків при їх застосуванні.

Також важливою стороною клінічної дії SAM слід визнати наявність у нього за рахунок нейропротекторних властивостей прокогнітивного ефекту [8]. Як відомо, когнітивні порушення $\epsilon$ одним із провідних симптомокомплексів при всіх формах афективних розладів $[15,19,20]$ і важливим фактором десоціалізації пацієнтів. Тому можливість одномоментної корекції порушень афективної та когнітивної сфер може бути ще однією цінною характеристикою SAM як лікарського засобу. 
На особливу увагу заслуговують властивості SAM як тимостабілізатора, тобто інструменту лікування пацієнтів із різними формами дистимії. Це важливо у зв'язку з виявленим фактом переважної ефективності SAM при анергічних афективних розладах, що супроводжуються, крім пригнобленого настрою, також млявістю, гіперсомнією, відсутністю мотивації. Подібна симптоматика характерна для таких клінічних форм, як сезонний афективний розлад, афективні порушення при неврозах і психосоматичній патології, клімактеричному синдромі тощо [8], тобто в ситуаціях, які часто не вимагають сильнодіючої фармакотерапії у вигляді «класичних» антидепресантів, і де на перше місце виходять фізіологічність і швидкість дії, а також особливо важливі параметри безпеки. Саме останній критерій $\epsilon$ ще однією значущою перевагою SAM перед препаратами антидепресантів. Частота побічних ефектів при застосуванні SAM наближається до такої плацебо. До них можна віднести епізоди слабкості, нудоту, відчуття серцебиття. Для SAM не характерні ніякі серйозні побічні ефекти. Для запобігання потенційному і вкрай незначному ризику розвитку серотонінового синдрому при комбінації SAM із препаратами СІ33С і СІ33С слід починати терапію з мінімальних рекомендованих доз (200-400 мг/добу) і підвищувати їх лише за ретельної оцінки співвідношення ризик/користь. Саме зазначені дози необхідно розглядати як оптимальні при монотерапії SAM у пацієнтів із дистимічними розладами або при застосуванні у ролі аугментації терапії конвенційними антидепресантами.

Узагальнюючи, SAM сьогодні можна оцінити як перспективний, але недооцінений засіб терапії у пацієнтів із афективними розладами як альтернативи або доповнення при застосуванні антидепресантів.

Інші біологічно активні речовини у складі комплексу Депріліум ${ }^{\circledast}$ разом із SAM формують своєрідний єдиний нейрометаболічний ланцюжок, спрямований на активацію синтезу біогенних амінів і реалізацію їхньої фізіологічної ролі.

L-метилфолат (фолієва кислота) - біологічно активна форма фолату, що легко проникає через гематоенцефалічний бар'єр у мозок і відіграє ключову фізіологічну роль в біосинтезі нуклеотидів і ферментів, зокрема $\epsilon$ попередником в біосинтезі ендогенного SAM [21]. Таким чином, ці два компоненти комплексу Депріліум ${ }^{\circledast}$ знаходяться у тісній фізіологічній єдності, будучи пов'язаними між собою в реакціях метилювання в ЦНС. 3 цього випливає, що поєднання SAM i L-метилфолату може зумовлювати синергічну дію щодо цих реакцій. Крім того, L-метилфолат, як і SAM, $\epsilon$ незамінним кофактором у біосинтезі $\mathrm{BH}_{4}$. Ця сполука необхідна для активації двох основних ферментів біосинтезу біогенних амінів - триптофангідроксилази і тирозингідроксилази, що визначають утворення в мозку серотоніну, дофаміну і норадреналіну [19].

При депресії відзначається дефіцит L-метилфолату в ЦНC, що розглядають як важливий фактор ослаблення активності біогенних амінів і формування клінічної афективної симптоматики [21]. Більше того, дефіцит фолату у ЦНС служить значущим фактором ризику подальшої резистентності до терапії антидепресантами, а також погіршення прогнозу у процесі терапії $[21,22]$.

У клінічній практиці застосування L-метилфолату показало найвищу ефективність як інструменту стратегії аугментації при недостатній відповіді на СІ33С (флуоксетин) [23, 24]. Особливо доцільне застосування цієї комбінації при класичній меланхолійній депресії. У великому рандомізованому плацебо-контрольованому дослідженні включення в схему лікування пацієнтів із великим депресивним розладом L-метилфолату в дозі до 0,5 мг/добу протягом 8 тиж показало наявність вираженої клінічної відповіді у 93\% пацієнтів проти 61\% у контрольній групі, при цьому обидві групи пацієнтів отримували флуоксетин як базову терапію [24]. Тому застосування L-метилфолату, особливо у поєднанні з SAM, може бути дієвим інструментом стратегії аугментації у ряду пацієнтів-нонреспондерів, або при недостатній відповіді на терапію CI33С, або при поганій переносимості конвенційних антидепресантів у рамках рутинних дозових схем. Також з огляду на взаємозалежність SAM і фолату в метаболіч- них ланцюгах і відповідно їх взаємозв'язок у патогенезі всіх видів афективних розладів перспективною виглядає їх терапевтична комбінація в лікуванні у разі різних форм дистимії. Нарешті висока безпека L-метилфолату в терапевтичних дозах і мінімальна кількість і рідкість побічних ефектів (нудота, слабкість, алергічні висипання, діарея) дозволяють обґрунтувати його переваги (як i SAM) перед препаратами ТЦА, CI33C і Cl33CH щодо мінімізації ризиків терапії.

Метилкобаламін - третя опорна точка у складі комплексу Депріліум ${ }^{\circledast}$, яка завершує обгрунтування поєднання його компонентів стосовно фармакологічного і клінічного синергізму дії.

Порівняно з іншими формами вітаміну $\mathrm{B}_{12}$ метилкобаламін на субклітинному рівні краще транспортується в органели нейронів. Саме завдяки цій властивості він ефективний для поліпшення психоемоційного стану та нормалізації функціонування нервової системи. Активна форма вітаміну B ${ }_{12}$, як і L-метилфолат, $\epsilon$ попередником в ланцюзі біосинтезу SAM в організмі. При депресії приблизно у 20\% пацієнтів виявлено зниження рівня вітаміну $\mathrm{B}_{12}$ у крові, причому воно корелює з клінічною тяжкістю захворювання [25]. Аналогічно з L-метилфолатом пацієнти 3 низькими рівнями вітаміну $B_{12}$ характеризуються гіршою відповіддю на терапію антидепресантами [22], тому цей параметр можна розглядати як предиктор ефективності лікування паці$\epsilon$ нтів із депресією. Додавання вітаміну $B_{12}$ (1 мг/добу) до препаратів CI33C у резистентних пацієнтів покращувало відповідь на терапію при оцінці за шкалою HAM-D через 6 тиж лікування [26]. Зазначений ефект зберігався протягом наступного терміну (до 26 тиж) вже у вигляді монотерапії CI33C і перевершував параметри тимоаналептичної дії у пацієнтів, які з самого початку терапії отримували лише препарати CI33C, що свідчить про довгостроковий ефект вітаміну $B_{12}$ як засобу аугментації. I хоча далеко не всі аспекти ролі вітаміну $\mathrm{B}_{12}$ в патогенезі афективних розладів і його місця в фармакотерапії депресії детально вивчені, вже зараз, враховуючи біохімічний синергізм його механізмів дії з ефектами SAM i L-метилфолату у процесах біосинтезу і фізіологічних ефектах біогенних амінів, можна вважати цілком обгрунтованим комбіноване застосування зазначених біологічно активних речовин.

Таким чином, комплекс Депріліум ${ }^{\circledast}$ передбачає реалізацію принципово іншого - нейрометаболічного - підходу в стратегії корекції афективних розладів. При відповіді на запитання, винесені у заголовок цієї статті, слід виходити з таких положень:

1. Комплекс Депріліум ${ }^{\circledast}$ можна ефективно вживати як окремо - у пацієнтів з усіма формами дистимічних розладів, при депресії невротичної та психосоматичної природи легкої та середньої тяжкості (за наявності протипоказань, непереносимості або відмови пацієнтів від прийому конвенційних антидепресантів), так і в рамках стратегії аугментації - спільно з ТЦА, СІ33С або $\mathrm{Cl} 33 \mathrm{CH}$ у пацієнтів із великим депресивним розладом при відсутності або слабкій вираженості клінічної відповіді на антидепресанти, або у разі виникнення дозозалежних побічних ефектів (з метою зниження дози антидепресанту).

2. Додатковим аргументом на користь вживання комплексу Депріліум ${ }^{\circledast}$ слід вважати наявність клінічно значущої когнітивної дисфункції при всіх формах афективних розладів, а також наявність клінічних форм депресії з переважанням анергічної симптоматики.

3. Комплекс Депріліум ${ }^{\circledast}$ не рекомендується вживати пацієнтам із тяжким великим депресивним розладом, при біполярній депресії і в поєднанні з препаратами, що підвищують згортання крові.

4. Комплекс Депріліум ${ }^{\circledast}$ протипоказаний при індивідуальній непереносимості його окремих компонентів; в дитячому віці, в період вагітності й годування грудьми (оскільки відсутні спеціальні дослідження з безпеки у цих пацієнтів); при злоякісних новоутвореннях і хворобах системи крові (загальне протипоказання для всіх фолат- і вітамін $\mathrm{B}_{12}$-вмісних препаратів і вітамінних комплексів).

5. Комплекс Депріліум ${ }^{\oplus}$ рекомендується вживати по 1-2 капсули на добу, що відповідає численним клінічним дослідженням, 
які підтверджують доцільність застосування зазначених компонентів при афективних розладах саме у цих дозах. Оптимальний курс вживання становить 1-3 міс з можливістю повторення після ретельної оцінки ефективності і переносимості.

Підсумовуючи зазначимо, що нейрометаболічна стратегія лікування пацієнтів із афективними розладами значною мірою $\epsilon$ новим напрямком для вітчизняної клінічної практики. Саме тому максимально широка апробація комплексу Депріліум ${ }^{\circledast}$ у неврологічній, психіатричній та загальномедичній практиці дозволить виявити її реальні переваги і оцінити її місце у клінічній нейропсихофармакології і терапії.

Конфлікт інтересів: відсутній.

Conflict of interests: the author declare no conflict of interests.

\section{Список використаної літератури/References:}

1. Kupko N. (2019) Screening and diagnosis of depression in primary care. HeйpoNews, 9(110): 24-28 (In Ukr.).

2. Ferrari A.J., Charbos K.J., Norman R.E. et al. (2013) The epidemiological modeling of major depressive disorder: application to the Global Burden of Disease Study 2010. PLOS One (https:// doi.org/10.1371/journal.pone.0069637).

3. Maruta N.A. (2001) Modern depressive disorders (clinical and psychopathological features, diagnosis, therapy). Ukr. Bull. Psychoneurol., 9(4): 79-82. (In Rus.)

4. Montgomery S.A. (2006) Why do we need vew and better antidepressants? Int. Clin. Psychopharmacol., 21(Suppl. 1):S1-S10.

5. Bosker F.J., Westerink B.H., Cremers T.I. et al. (2004) Future antidepressants: what is in the pipeline and what is missing? CNS Drugs, 18: 705-732.

6. Fuchs E., Simon M., Schmelting B. (2006) Pharmacology of a new antidepressant: benefit of the implication of the melatonergic system. Int. Clin. Psychopharmacol., 21(Suppl. 1): S17-S20.

7. Schatzberg A., DeBattista C. (2015) Manual of Clinical Psychopharmacology (Eight Ed.). Amer. Psychiat. Publ., Washington, $687 \mathrm{p}$.

8. De Berardis D., Orsolini A., Serroni N. et al. (2016) A comprehensive review on the efficacy of Sadenosyl-methionine in major depressive disorder. CNS \& Neurol. Disord. Drug Target, 15: 1-10.

9. Spillmann M., Fava M. (1996) S-adenosyl-methionine (ademethionine) in psychiatric disorders. CNS Drugs, 6: 416-425.

10. Papakostas G.L.,Mishoulon D., Shyu I. etal. (2010) S-adenosyl-methionine (SAMe) augmentation of serotonin reuptake inhibitors for antidepressants nonresponders with major depressive disorder: a double-blind, randomized clinical trial. Am. J. Psychiat., 167: 942-948.

11. Alpert J.E., Papakostas G., Mochoulon D. (2008) One-carbon metabolism and the treatment of depression: roles of S-adenosyl-methionine and folate. Natural Medications for Psychiatric Disorders. Considering the Alternatives, 2nd ed. Lippincott \& Co, PA, 68-83 p.

12. Bell K.M., Potkin S.G., Carreon D. et al. (1994) S-adenosyl-methionine blood levels in major depression: changes with drug treatment. Acta Neurol. Scand., Suppl., 154: 15-18.

13. Mischoulon D., Fava M. (2002) Role of S-adenosyl-methionine in the treatment of depression: a review of the evidence. Am. J. Clin. Nutr., 76 (suppl.): 1158S-1161S.

14. Papakostas G.L., Thase M.F., Fava M. et al. (2007) Are antidepressant drugs that combine serotonergic and noradrenergic mechanisms of action more effective than the selective serotonin reuptake inhibitors in treating major depressive disorder? A metaanalysis of studies of newer agents. Biol. Psychiat., 62: 1217-1227.

15. Duman R.S. (2004) Theories of depression — from monoamines to neuroplasticity. Neuroplasticity: a new approach to the pathophysiology of depression. Sci. Press, London, 1-12 p.

16. Papakostas G.I., Pancheri P., Scapicchio P., Chiare R.D. (2002) A double-blind, randomized, parallel-group efficacy and safety study of intramuscular S-adenosyl-methionine 1,4-butanedisuphonate (SAMe) versus in patients with major depressive disorder. Int. J. Neuropsychopharmacol., 5: 287-294.

\footnotetext{
Відомості про автора: України», Київ, Україна

Адреса для кореспонденції:

Бурчинський Сергій Георгійович

04114, Київ, Вишгородська, 67

E-mail:bsg@geront.kiev.ua
}

Бурчинський Сергій Георгійович — кандидат медичних наук, завідувач відділу інформаційного аналізу Державної установи «нститут геронтології імені Д.Ф. Чеботарьова НАМН
17. Alpert J.E., Papakostas G., Mischoulon D. et al. (2004) S-adenosyl-methionine (SAMe) as an adjunct for resistant major depressive disorder: an open trail following partial or nonresponse to selective serotonin reuptake inhibitors or venlafaxine. J. Clin. Psychopharmacol., 24: 661-664.

18. Sarris J., Papakostas G.L., Vitolo 0. et al. (2014) S-adenosyl-methionine (SAMe) versus escitalopram and placebo in major depression RCT: efficacy and effects of histamine and carnitine as moderators of response. J. Affect. Disord., 164: 76-81.

19. Burchinsky S.G. (2018) Pharmacotherapy of post-stroke depression: the problem and criteria for choosing an antidepressant. НейрoNews, 6: 37-41 (In Rus.).

20. Parfenov V.A. (2012) Post-stroke depression: prevalence, pathogenesis, diagnosis and treatment. Nevrol. neuropsychiatrist. psychosomat., 4: 84-88 (In Rus.).

21. Fava M., Borus J.S., Alpert J.E. et al. (1997) Folate, vitamin $B_{12}$ and homocysteine in major depressive disorder. Am. J. Psychiat., 154: 426-428.

22. Gilbody S., Lightfoot T., Sheldon T. (2007) Is low folate a risk factor for depression? A metaanalysis and exploration of heterogeneity. J. Epidemiol. Commun. Health, 61: 631-637.

23. Papakostas G.I., Petersen T., Lebowitz B.D. et al. (2005) The relationship between serum folate, vitamin $B_{12}$ and homocysteine levels in major depressive disorder and the timing of improvement with fluoxetine. Int. J. Neuropsychopharmacol., 8: 523-528.

24. Papakostas G.L., Shelton R.C., Zajecka J.M. et al. (2012) L-methylfolate as adjunctive therapy for SSRI-resistant major depression: results of two randomized, double-blind, parallel-sequential trials. Am. J. Psychiat., 169: 1267-1274.

25. Coppen A., Bollander-Gouaille C. (2005) Treatment of depression: time to consider folic acid and vitamin $B_{12}$. J. Psychopharmacol., 19: 59-65.

26. Sved E.U., Wasay M., Awan S. (2013) Vitamin $B_{12}$ supplementation in treating major depression disorder: a randomized controlled trials. Open Neurol., 7: 44-48.

\section{Neurometabolic strategy of pharmacotherapy of affective disorders: whom, when and why?}

\section{S.G. Burchinsky}

State Institution «D.F. Chebotarev's Institute of Gerontology of the NAMS of Ukraine», Kyiv, Ukraine

Abstract. One of the most important from a clinical point of view problems related to the diagnosis and treatment of depression, especially in general medical and neurological practice, is a significant increase in affective disorders, called dysthymia, i.e. psychoemotional states characterized by mood swings or predominance of reduction of psycho-emotional state, a feeling of depression, indifference, which however is not stable and is periodically replaced by «normal» perception of themselves and others. Such conditions, not being depression in the strictly nosological sense of the term, may precede the development of depressive disorder, and may be characterized by stability for a long time. In dysthymia, the appointment of «classic» antidepressants is not always indicated. In this situation, the so-called thymo-stabilisers, or mood correctors, may be more useful - drugs with a mild complex mechanism of action on the psycho-emotional sphere, which increase mood and vitality without a pronounced effect on psychopathological symptoms. An innovative domestic complex Deprilium ${ }^{\circledast}$, which includes S-adenosyl-L-methionine, L-methylfolate and methylcobalamin, is fundamentally different from conventional antidepressants and characterizes another strategy of action - neurometabolic.

Key words: affective disorders, depression, depressive disorders, dysthymia, antidepressants, thymo-stabilisers, Deprilium ${ }^{\circledast}$, S-adenosyl-L-methionine, L-methylfolate, methylcobalamin.

\section{Information about the author:}

Burchinsky Sergiy G. - Candidate of Medical Sciences, Head of the Department of Information Analysis of State Institution «D.F. Chebotarev's Institute of Gerontology of the NAMS of Ukraine», Kyiv, Ukraine

Address for correspondence:

Sergiy Burchinsky

04114, Kyiv, Vyshgorodska str., 67

E-mail: bsg@geront.kiev.ua 